\title{
The New European Network on Victims' Rights
}

\section{Ivana Gážiová \& Jan Kralik}

\author{
Pan-European University in Bratislava, Faculty of Law, Slovakia; \\ Charles University in Prague, Faculty of Law, Czech Republic \\ ivana.gaziova@justice.sk; jan.kralik@justice.sk
}

GÁŽIOVÁ, Ivana; KRÁLIK, Ján. Unveiling the overlooked freedom - the context of free movement of capital and payments in the EU law. International and Comparative Law Review, 2016, vol. 16, no. 1, pp. 83-95. DOI: 10.1515/iclr2016-0006.

\begin{abstract}
Summary: The Netherlands, Slovakia, France and Ireland are the States that came up with the initiative to establish a European Network on Victims' Rights. This project is financed by Action grant of the European Commission and partially by Netherlands. The aim of this paper is to give general information about the main goals of the network and current work of Member States in the area of victims' rights. The information is simply structured and composes of one main chapter and two subchapters. The first subchapter is divided into four paragraphs reflecting the framework of the network while the second one descriptively informs about the Council conclusions adopted during Netherlands' presidency that confirmed the existence of the network.
\end{abstract}

Keywords: compensations, cross-border cases, European Network on Victims' Rights, ENVR, individual assessment, SK PRES, victim, victims' rights.

\section{Introduction}

Several years ago, victims had only few rights that were also encompassed within the domestic legal order of respective States. ${ }^{1}$ Among those were mainly rights to be heard, informed and present within the criminal justice systems. Notwithstanding these important guarantees, we may only label them as exception confirming the rule defining that more extensive rights pertaining to victims of crime were not even codified but largely absent. Among most important rights that were omitted from various legal systems was right to be informed about the arrest or release of potential perpetrator of the crime. Usually, the victims were also not notified about the court proceedings which meant that the presence of the perpetrator was unknown to them.

1 From historical point of view two types of procedures coexist within criminal judicial framework. Whereas the adversarial system does not grant no formal standing to the victim, i.e. the victim serves only as a prosecutorial witness; inquisitorial model preferred within continental Europe has recognized victim as a party with his or her own rights. FISHER, Bonnie, Sue, LAB, Steven P. Encyclopedia of Victimology and Crime Prevention. Volume I. SAGE Publications, Thousand Oaks, 2010, p. 1015. 
Nevertheless, in recent years the topic of victims of crime has been given considerable attention at the EU level. It is evident that cultural, social and political developments over last decades enabled victims' rights to be part of EU legislation which arose in numerous different initiatives. This paper reacts on the recent activity of the European Union ensuring the efficiency of EU law concerning victims. Nowadays, the result is that victims' rights are more established in our jurisdictions. It flows from existing EU legislative acts in the area of victims' rights that the EU is eager to protect victims of crimes. ${ }^{2}$ For this purpose it has created legal framework for establishing minimal standards on the rights, support and protection of victims of crime.

The Lisbon Treaty established precise EU competence to adopt legislative measures on the rights of victims of crime $^{3}$ and the Stockholm programme came with the intention to establish an integrated and coordinated approach towards victims within the EU. More specifically, after the adoption of Lisbon Treaty that stipulates minimal standards applicable in the Member States with the purpose to facilitate mutual recognition of judgments and other judicial decisions and police and judicial cooperation in criminal matters with crossborder character, the endeavours of the EU have acquired a new dimension. This concerns in a more substantive way also victims of crimes and their rights. Same pronouncements about concrete steps were also made by the Council of the European Union. Furthermore, on the basis of Stockholm Programme - An open and secure Europe, the Commission and Member States were asked to examine how to improve legislation and practical support measures for protection of victims with regard to special attention, support and recognition of the priority given to all victims of crime. ${ }^{4}$

The actual work of Member States was additionally translated into the creation of the European Network on Victims' Rights (hereinafter "ENVR"). It concentrates on further reinforcement of the position of victims not only in criminal but also in civil matters within the entire EU area. ${ }^{5}$ It is to be noted that

2 See EU Council, The Stockholm Programme - An open and secure Europe serving and protecting the citizens, 2 December 2009, 17024/09 [online]. Available at: <http://eur-lex. europa.eu/legal-content/EN/TXT/HTML/?uri=URISERV:j10034\&from=EN > Accessed: 21.07.2016

3 European Union, Treaty of Lisbon Amending the Treaty on European Union and the Treaty Establishing the European Community, 13 December 2007, 2007/C 306/01, Art. 69A para. 2, letter c) [online]. Available at: $<$ http://eur-lex.europa.eu/legal-content/EN/ALL/?u ri=OJ\%3AC\%3A2007\%3A306\%3ATOC > Accessed: 21.07.2016.

4 POLÁK, Peter. Legal regulation of status of aggrieved parties (victims) in criminal proceedings in context of current European Union legislation requirements. In Obete kriminality a ich práva: Zborník príspevkov zo seminára $z$ medzinárodnou účastou konaného dňa 6. novembra 2014 na Fakulte práva Paneurópskej vysokej školy v Bratislave. Žilina: Spoločnost̉ pre trestné právo a kriminológiu, 2015, p. 36.

5 At the beginning of 2015 Netherlands, Slovakia, France and Ireland applied for an Action Grant of the Commission for the project of European network for victims 'rights that was 
reinforcement of the position of victims is an important step that has to be done by laying down their rights in EU legislation. However, victims will only have a full-fledged position when they can exercise their rights in practice and actually get the support and protection they need from Member States.

\section{The role of a Victim as defined by Victims' Directive}

\subsection{Comparison to other instruments}

As we have mentioned above, victims' rights were neither increasingly enshrined in national legislations nor could they be found in any global or regional legally binding instruments. After several reminders of unquestionable relevance of the topic, ${ }^{6}$ a slight shift towards more explicit rules encompassing protection of victims was observed. With regard to first international law documents concerning victims' rights, Rover as quoted by Viktoryová and Blatnický has mentioned UN Declaration of Basic Principles of Justice for Victims of Crime and Abuse of Power adopted within the UN General Assembly in 1985. ${ }^{7}$ Novokmet further points out to the United Nations Convention Against Transnational Organized Crime adopted in 2000 and the United Nations Convention Against Corruption of 2003 respectively which both contain explicit provisions concerning procedural rights of victims. ${ }^{8}$

In the following lines we will put our focus on Directive 2012/29/EU of the European Parliament and of the Council of 25 October 2012 establishing minimum standards on the rights, support and protection of victims of crime

later confirmed by Council conclusions on establishing an Informal European network for victims' rights. With reference on the identified legislation it is evident that it involves both criminal and civil law approach.

6 The topic started evolving in the 1960s when women's groups and feminists groups brought attention to the "plight of rape victims." FINKELMAN, Paul. Encyclopedia of American Civil Liberties. Volume I. New York: Routledge, 2006, p. 1710.

7 VIKTORYOVÁ, Jana, BLATNICKÝ, Jaroslav. Rights, support and protection of victims from the perspective of criminal investigation. In Obete kriminality a ich práva: Zborník príspevkov zo seminára $z$ medzinárodnou účastou konaného dña 6. Novembra 2014 na Fakulte práva Paneurópskej vysokej školy v Bratislave. Žilina: Spoločnost pre trestné právo a kriminológiu, 2015, s. 133. [VIKTORYOVÁ, BLATNICKÝ, 2015]. Although aforementioned declaration has been clearly a non-binding, i. e. so-called soft-law instruments adopted by the UN General Assembly, importance of such proclamations was fostered by referring to them in practice by some important legal authorities. During the infamous Milosević trial before the International Criminal Tribunal for Yugoslavia, the Prosecutor Carla del Ponte as well as the leading Prosecution counsel, Geoffrey Nice referred repeatedly to the victims in their speeches. More importantly, Carla del Ponte emphasised the priority of victims' rights when she unequivocally called for the joinder of the three indictments against Milosević. LAUGHLAND, Jon. Travesty: The Trial of Slobodan Milosević and the Corruption of International Justice. First Edition. London: Pluto Press, 2007, p. 84.

8 NOVOKMET, Ante. The Right of a Victim to a Review of a Decision not to Prosecute as Set out in Article 11 of Directive 2012/29/EU and an Assessment of its Transposition in Germany, Italy, France and Croatia. Utrecht Law Review, 2016, roč.12, č. 2, p. 87. 
(hereinafter "Victims' Directive") provides in general a wider scope of procedural rights of the victim. The aim of Victims' Directive is the revision and supplementation of principles stated in Council Framework Decision 2001/220/JHA of 15 March 2001 on the standing of victims in criminal proceedings in order to improve the protection of victims' rights within the EU (hereinafter "Framework Decision"), ${ }^{9}$ mainly in criminal proceedings. Framework Decision as stated by Groenhuijsen and Pemberton was the first hard-law instrument concerning victims of the crime at the international level. ${ }^{10}$ Although big hopes were put into it, its implementation was not successful. In 2009 the Commission stated that the national legislation of many Member States contains numerous omissions and reflect existing practice before the adoption of the Framework Decision. ${ }^{11}$ On the other hand, the Framework Decision referenced above, remains applicable to Denmark even after the transposition deadline for the Victims' Directive has passed for the other 27 Member States (Recital 71 of the Preamble of the Victims' Directive) since Denmark has not adopted it. ${ }^{12}$ Therefore, in judicial cooperation with Denmark the respective regime according to Council Framework Decision is to be maintained.

In this context, it is interesting to note that the Slovak Republic, like some other Member States, has not yet fully transposed the Victims' Directive. What is noteworthy, the Slovak Republic puts its endeavors towards the protection of victims' rights flowing from Victims' Directive. In particular, as one of the cofounders of the ENVR, it organizes the Second meeting of the European Network on Victims' Rights which will be held in Bratislava on 21 November 2016 during the Slovak presidency in the Council of the EU. ${ }^{13}$ Significance of the topic of victims' rights is enhanced also by the fact that the European Judicial Network in criminal matters will organize several workshops in margins of its plenary meeting on 22-23 November $2016 .^{14}$

9 See European Union: Council of the European Union, Council Framework Decision of 15 March 2001 on the standing of victims in criminal proceedings, 2001/220/JHA, 15 March 2001 [online]. Available at: < http://eur-lex.europa.eu/legal-content/EN/TXT/PDF/?uri=C ELEX:32001F0220\&from=EN > Accessed: 28.07.2016.

10 GROENHUIJSEN, Marc, PEMBERTON, Antony. The EU Framework Decision for Victims of Crime: Does Hard Law Make a Difference? European Journal of Crime, Criminal Law and Criminal Justice, 2009, roč. 17, č. 1, p. 43.

11 GROENHUIJSEN, Marc. The development of international policy in relation to victims of crime, International Review of Victimology, 2014, roč. 20, č. 1, p. 36.

12 MAIZENER, Linda, et al. EVVI (Evaluation of Victims), The Ministry of Justice of the French Republic, 2013, p. 7. [online]. Available at: <http://www.justice.gouv.fr/publication/evvi_guide_en.pdf $>$ Accessed: 01.08.2013

13 For further information regarding this event kindly consult <http://www.eu2016.sk/en/ political-and-expert-meetings/second-meeting-of-the-european-network-on-victimsrights $>$.

14 For further information kindly consult $<$ https://www.ejn-crimjust.europa.eu/ejn/Eventsdetail.aspx?event $=428>$. 
One of new approaches of the Directive is more profiled cooperation and coordination of services. This has resulted in fact to the establishment of an Informal European Network on Victim's Rights. Due to this achievement and to the binding force of the Victims' Directive, it may be characterized as a bigger step towards better protection of victims' rights and harmonization of procedural rules in EU Member States.

\subsection{Elaboration of Victims' Directive provisions}

The aim of the Victims' Directive is to ensure that "victims of crime receive appropriate information, support and protection and are able to participate in criminal proceedings, ${ }^{15}$ In contrast to abovementioned Framework Decision The Victims' Directive contains more exhaustive definition of a victim in its Art. 1 a), it describes victim as:

(i) a natural person who has suffered harm, including physical, mental or emotional harm or economic loss which was directly caused by a criminal offence; (ii) family members of a person whose death was directly caused by a criminal offence and who have suffered harm as a result of that person's death, ${ }^{16}$

Furthermore, the important aspect enshrined in the Victims' Directive is the right to receive information from the first contact with a competent authority as stipulated by Article $4 .{ }^{17}$ Rover, as quoted by Viktoryová and Blatnický points out that focus on due consideration will partially remove negative consequences of the offense committed and helps to create trust towards law enforcement authorities. $^{18}$

This issue is closely connected to the educational level of the society. The awareness of the society is very low and victim learns about his/her rights and responsibilities at the first contact with the competent authorities which can be too late with respect to his/her psychological or physical damage suffered by the crime.

Victims' Directive in its Art. 4 para 1 regulates the list of rights that need to be given to the victim from the first contact with a competent authority. ${ }^{19}$ Medelský provides for following suggestions for improvements relating to the better

15 European Union: Council of the European Union, Directive 2012/29/EU of the European Parliament and of the Council of October 2012 establishing minimum standards on the rights, support and protection of victims of crime, and replacing Council Framework Decision 2001/220/JHA, 14 November 2012, L 315/57, Art. 1 para 1 [online]. Available at: $<$ http://eur-lex.europa.eu/LexUriServ/LexUriServ.do?uri=OJ:L:2012:315:0057:0073:EN:P DF> Accessed 28.07.2016 [Directive, 2012].

16 Ibid., Art. 2 para. 1 letter a).

17 Ibid., Art. 4.

18 VIKTORYOVÁ, BLATNICKÝ, 2015, supra note 7, p. 133.

19 Article 4 Para 1, letters a-k of the Directive 2012/29/EU list the categories of rights that need to be addressed. 
education offered to public society and organization of trainings for persons of the first contact with victims:

- to provide better education offered at secondary school and/or Police Academy,

- trainings for people of first contact, such as police officers, prosecutors, judges, probation and mediation officers and other entities that come into contact with victims of crime.

Moreover, police needs to know how to interpret necessary information to the victim reflecting the particularities of specific cases. The list elaborated in Art. 4 para 1 provides some new provisions establishing more rights of victims and it may be agreed with the opinion of Medelsky that it is not enough if the policeman learns how to interpret these rights by practice. ${ }^{20}$ This Article reads as follows:

"Member States shall ensure that officials likely to come into contact with victims, such as police officers and court staff, receive both general and specialist training to a level appropriate to their contact with victims to increase their awareness of the needs of victims and to enable them to deal with victims in an impartial, respectful and professional manner."

In connection to this, Medelský is of the opinion the police is able to fulfill such requirement. It is also to be noted that such trainings could be organized also with assistance of the Commission or even ENVR.

Comparing the 2012 Directive with the prior Framework Decision, it provides for a wider definition of victim by including also family members. Furthermore, the rules on cooperation between Member States' authorities have been expanded and it contains new provisions requiring Member States to make victims more aware of their rights which can be seen by the wording of Art. $26 .{ }^{21}$ Art. 26 para 1 of the Victims' Directive enshrines that Member States shall take appropriate action to facilitate cooperation between them to improve victims' access to the rights set out in the directive and under national law. This respective article is also the legal basis for creation of Informal European Network on Victim's rights. ${ }^{22}$

DG Justice Guidance Document further specifies the importance of communication between Member States and the establishment of national contact

20 MEDELSKÝ Jozef. Actual and future regulation of victims' rights in the Slovak republic. In Obete kriminality a ich práva: Zborník príspevkov zo seminára $z$ medzinárodnou účastou konaného dňa 6. novembra 2014 na Fakulte práva Paneurópskej vysokej školy v Bratislave. Žilina: Spoločnost' pre trestné právo a kriminológiu, 2015, p. 222. [MEDELSKÝ, 2015].

21 For the comparison with the 2001 Framework Decision see PEERS, Steve. Guidelines for Transposition. The EU Directive on Victims' Rights (2012/29/EU) and homophobic and transphobic crime victims. Human Rights Centre, University of Essex, 2013, p. 7.

22 [Directive, 2012], supra note 17, Art. 26 para 1. 
points who are advised to share their best practices and cooperate via networks of national contact points through several platforms within the EU. ${ }^{23}$ The network fulfills this aim of the Victims' Directive by enabling member states to share their knowledge and best practices, stimulate cooperation in cross-border cases and organize meetings of contact points for these purposes. This requirement flows also from Art. 47 of the EU Charter of Fundamental rights that guarantees to all the right to effective access to justice. ${ }^{24}$

\section{The project of the European Network for Victims' Rights}

\subsection{General Information}

The project of creation of the ENVR was initiated by the Netherlands, leading the project together with their co-founders Slovakia, France and Ireland. ${ }^{25}$ Support and establishment of ENVR was stated in an 18 month Trio presidency programme. ${ }^{26}$ The existence of the network is based on the action grant that will end in May 2017. According to Article D Para 10 of the Council conclusions the ENVR should evaluate its work in consultation with the Commission in order to decide on the need of its continuation. ${ }^{27}$ In this respect we need to point out that the idea of the permanent ENVR is not excluded. The support of this idea could be found also in the fact that Commission is opening together two new calls for proposals offering action grants to support transnational projects to enhance the rights of victims of crime.

23 European Union: European Commission, DG JUSTICE GUIDANCE DOCUMENT related to the transposition and implementation of Directive 2012/29/EU of the European Parliament and of the Council of 25 October 2012 establishing minimum standards on the rights, support and protection of victims of crime, and replacing Council Framework Decision 2001/220/JHA, 2013, p. 49.

24 Art. 47 reads as follows: "Everyone whose rights and freedoms guaranteed by the law of the Union are violated has the right to an effective remedy before a tribunal in compliance with the conditions laid down in this Article. Everyone is entitled to a fair and public hearing within a reasonable time by an independent and impartial tribunal previously established by law. Everyone shall have the possibility of being advised, defended and represented. Legal aid shall be made available to those who lack sufficient resources in so far as such aid is necessary to ensure effective access to justice." European Convention, Charter of Fundamental Rights of the European Union, 2012/C 326/02, 2 October 2000, Art. 47.

25 Slovak Republic, as one of the partners joined to the Netherlands' initiative in accordance with the 18 month TRIO PRES programme that calls for supporting the establishment of a European Network on Victims' Rights.

26 European Union: Council of the European Union, 18 month programme of the Council, 1 January 2016-30 June 2017 [online]. Available at: <data.consilium.europa.eu/doc/document/ST-12396-2015-INIT/en/pdf> Accessed: 28.07.2016

27 European Union: Council of the European Union, Council conclusions establishing an Informal European Network on Victims' Rights, 9 June 2016, Article D Para 10 [online]. Available at: <http://data.consilium.europa.eu/doc/document/ST-9997-2016-INIT/en/ pdf $>$. Accessed 28.07.2016. [Council Conclusions, 2016]. 
The priorities of the first project could be found on the website of the Commission $^{28}$, but mostly they are concerned on the implementation and practical application of the instruments that corresponds with the aims of the ENVR. Furthermore, it should be concentrated on:

- development of ways how to give relevant information about their rights, procedures, support, compensation system,

- finding a best way for cooperation in cross-border cases,

- improvement of procedures taking into account individual assessment.

The second project should be focused on discussions about new possible legislation, mainly on:

- identification of the needs that are missiong in current legislation,

- exchange of good practices among the Member States,

- analytical work regarding to collection of data, preparation of surveys.

Taking into account the Commission prepared the new call for proposal we can presume its interest in duration of the ENVR. Basically, meetings of ENVR have proved useful and replaced the expert meetings organized by the Commission. Member States have significant problems to transpose the Victim's Directive and it is logical they are reserved to present it in front of Commission. Therefore, the idea of the establishment of ENVR came up where Member States can discuss these problems and share their best practices. However, some of Member States objected the presence of the Commission at meetings of the contact points of ENVR. As to the fact Commission awards the action grant it was not possible to exclude it from meetings. Finally, the agreement was reached and the role of the Commission is not omitted, but limited only to the specific parts of the meeting.

Talking about the duration of ENVR, the interest of Member States is also evident that are now in the middle of discussions who will hold the leadership next. With regards to the fact that Malta, likewise Netherlands, has not nominated contact points of ENVR, hypothetically Estonia could be taken into account as the future presidency who also supported the existence of ENVR together with Hungary who showed a significant interest.

The role of the ENVR is to strengthen the rights of victims and to enhance the cooperation of the Member States in the area of victims' rights. It is a network of government officials, instrumental in enabling standards of the relevant EU legislation to work in day to day practice. It means that it serves to the public authorities in order to exchange their best practices concerning the implementation of the EU legislation in the area of victims' rights and cooperation in crossborder cases.

28 For priorities regarding the project kindly consult <http://ec.europa.eu/research/participants/portal/desktop/en/opportunities/just/topics/19097-just-jacc-vict-ag-2016.html> 
Among the most relevant legislation concerning victims the attention may be drawn to the Directive on minimum standards rights, support and protection of victims of crime $(2012 / 29 / \mathrm{EU})^{29}$ and Directive relating to compensation to crime victims $(2004 / 80 / \mathrm{EU})^{30}$. We would like to expand this short list on Directive European Protection order (2011/99/EU) ${ }^{31}$ and Regulation on mutual recognition of protection measures in civil matters $(606 / 2013) .{ }^{32}$ This point of view was also presented within the European network for victims 'rights that deals with all of the abovementioned instruments during its sessions and it was also confirmed by Council conclusions establishing an Informal European Network on Victims' Rights in its Article A Para $2 .^{33}$ Moreover, the preamble of the abovementioned Council Conclusions reacts to the numerous terrorist attacks. Therefore, the new draft of the directive on combating terrorism will be taken into account and the Article reflecting the rights of victims of terrorism is being discussed. ${ }^{34}$ This initiative reacts also on the Joint Statement of EU Ministers for Justice and Home Affairs and representatives of the EU Institutions adopted on 24 March 2016.

The difference of the ENVR from other networks is that it was created for competent public authorities implementing the relevant EU legislation in practice. With regard to the meetings of the contact points, these have been organised by the support group composed of Netherlands, Slovakia, France and Ire-

29 European Union: Council of the European Union, Directive 2012/29/EU of the European Parliament and of the Council of October 2012 establishing minimum standards on the rights, support and protection of victims of crime, and replacing Council Framework Decision 2001/220/JHA, 14 November 2012, L 315/57 [online]. Available at:

<http://eur-lex.europa.eu/LexUriServ/LexUriServ.do?uri=OJ:L:2012:315:0057:0073:EN:PDF> Accessed: 28.07.2016.

30 European Union: Council of the European Union, directive 2004/80/EC relating to compensation to crime victims, 29 April 2004, L 261/15 [online]. Available at: <http://eur-lex. europa.eu/LexUriServ/LexUriServ.do?uri=OJ:L:2013:181:0004:0012:en:PDF> Accessed: 28.07.2016

31 European Union: Council of the European Union, directive 2011/99/EU of the European Parliament and of the Council on the European protection order, 13 December 2012, L 398/2 [online]. Available at: <http://ec.europa.eu/justice/criminal/files/directive_2011_99_on_epo_en.pdf > Accessed: 28.072016

32 European Union: Council of the European Union, regulation (EU) No 606/2013 of the European Parliament and of the Council on mutual recognition of protection measures in civil matters, 12 June 2013 [online]. Available at:

<http://eur-lex.europa.eu/LexUriServ/LexUriServ.do?uri=OJ:L:2004:261:0015:0018:en:PDF> Accessed: 28.07.2016.

33 European Union: Council of the European Union, Council conclusions establishing an Informal European Network on Victims' Rights, 9 June 2016, Article A Para 2 [online]. Available at: <http://data.consilium.europa.eu/doc/document/ST-9997-2016-INIT/en/ pdf> Accessed: 28.07.2016. [Council Conclusions, 2016].

34 See e.g. European Union: European Commission, Proposal for a Directive of the European Parliament and of the Council on combating terrorism and replacing Council Framework Decision 2002/475/JHA on combating terrorism, 2015/0281 (COD), 2 December 2015, Title V. 
land, later joined by Hungary. The Member States have had a chance to discuss different topics leading to finding solutions for best implementations of the relevant EU legislation during the meetings, for instance, individual assessment, interpretation and translation, cross-border cases or access to information.

The preliminary meeting in Luxembourg and the first official meeting of the ENVR in Amsterdam was organised by the Netherlands with the assistance of the support group. The most important problems were identified and discussed in Amsterdam and suggestions were presented how to solve them. The second official meeting will take place in Bratislava under the Slovak presidency of the Council of the European Union that will concentrate more on practical solutions to the recognised problems. This meeting intends to concentrate on Article 4 of the Directive on minimum standards rights, support and protection of victims of crime $(2012 / 29 / \mathrm{EU})$ relating to the access to information in order to exchange of knowledge between national authorities, in particular, how they provide information to victims about their rights.

This approach partially covers information related to cross-border cases and system of compensations. The first step was already done in February at the meeting in Amsterdam during which this topic was classified as one of the most problematic issues. The focus of the Bratislava meeting will be put on finding concrete and practical solutions on exercising of victims' rights that are closely linked with the access to information that need to be easy and accessible. Moreover, it needs to be said that e-justice portal is sometimes unknown even among lawyers and besides that is too chaotic. That is why this e-justice portal will be part of the discussion.

\subsection{The framework of the ENVR}

The framework of the discussions of Member States is open but until now it was more or less concentrated on the access to information, individual assessment and cross-border cases.

\subsubsection{Access to information}

The directive constitutes 11 items of information that has to be offered to victims without unnecessary delay and from their first contact with a competent authority. On the same time, the way how they are communicated to victims must reflect their specific needs and expectations. Therefore, ENVR started discussions about the access for information with the intention to find the best way how to address them all to victims in a useful and proper way.

\subsubsection{Cross-border cases}

As far as cross-border cases, it is important to ensure that any victim can rely on the same basic level of rights whatever their nationality and wherever in the 
EU the crime takes place. ${ }^{35}$ It is even more difficult for victims to exercise their rights in cross-border cases. The way in which these rights may be exercised in practice requires inter alia a more detailed elaboration, expertise and engagement of more actors in order to achieve the whole picture. For instance, the right of a victim to report a crime that was committed in a foreign jurisdiction differs from State to State. Victims of serious crimes may face difficulties to report their victimisation to competent authorities. ENVR is a good platform where these particularities can be discussed.

\subsubsection{Compensations}

Apart from the difficult access to information, victims are often unaware of their rights and they do not have sufficient knowledge where to find support and assistance in terms of compensation services. This topic was opened during the Netherlands Presidency and deserves further discussions leading to simplification of the process of making a complaint or applying for compensation.

\subsubsection{Individual assessment}

Article 22 of Directive on minimum standards rights, support and protection of victims of crime (2012/29/EU) has the key role in Victims' directive and causes the huge practical problems for member states to implement it. That is why ENVR organised workshops during Amsterdam meeting to open discussions about individual assessment. This article is closely connected to provisions $23,24,18$ and 8 of the directive.

\subsection{Council conclusions establishing an Informal European Network on Victims' Rights}

Council conclusions that established the ENVR are systematically organized into Preamble and four chapters referring to objective, composition, organization, funding and evaluation of the network.

The first chapter states that network will facilitate and enhance the work of member states in order to fulfil the aims on which it was established regarding cooperation and exchange of best practices of the public authorities. ${ }^{36}$ The second paragraph refers to the fact that ENVR is composed of contact points of policy officers that will meet on regular basis with participation of the Commission and possibly other European institutions. The next paragraph contains information about organization and funding system of ENVR. The project is funded by the action grant ${ }^{37}$ and the meeting should be organized twice per year

35 European Union: Council of the European Union, Council conclusions establishing an Informal European Network on Victims' Rights, 9 June 2016, Preamble [online]. Available at: <http://data.consilium.europa.eu/doc/document/ST-9997-2016-INIT/en/pdf>. Accessed: 28.07. 2016. [Council Conclusions, 2016].

36 Council Conclusions, 2016, supra note 33, para A2.

37 Ibid., para C8. 
chaired by Member States. The last paragraph advices that ENVR should evaluate its work in consultation with the Commission.

\section{Conclusion}

It is right to say in the words of Čírtková as quoted by Havrlentová that it is practically impossible for a victim to prepare for a crisis situation in advance, it is even more difficult to live with this kind of experience and it is often almost impossible to avoid such situation. ${ }^{38}$ Once victims are part of this circle, it is hard for them to return back to normal life.

It is indisputable that to the victims of crimes is paid attention from the side of legislators, legal theorists and practitioners as well as the media. On the other hand we consider putting more attention to victims. We also agree with Mendelský who finds necessary to put more emphasis on these issues especially to the general public that is directly touched by this issue. He considers victim of crime is a person who is in a position where she has suffered injury or damage without their own fault. ${ }^{39}$

Therefore, it is important to find concrete and practical solutions for victims, not only at the national but also at the international level, such as the exercising of victims' rights in cross-border cases, maximizing synergies between compensation services, necessity of translation of documents and facilitation of international cooperation between States.

In this light, ENVR intends to pay more attention to the position of victims in cross-border cases. We support the idea relating to the exchange of knowledge between national authorities on the rights, protection and support of victims can make a good contribution to this. ENVR is the result of a need to organise experts' meetings in order to share their knowledge and best practices, promulgate guidelines, develop handbooks, adopt recommendations and gather information via questionnaires leading to uniform approaches and better protection of victims within EU Member States.

Last but not lest it is our duty to point out that even though Slovakia is one of the leaders of the ENVR it has not fully transposed the directive. The same applies for our colleagues, despite of the fact they are far ahead. They adopted law reflecting the previous framework decision, but not the directive. However, the explanatory report says something else according to Jelínek as quoted by

38 HAVRLENTOVÁ, Darina. Victim from psychological point of view. In Obete kriminality a ich práva: Zborník príspevkov zo seminára $z$ medzinárodnou účastou konaného dňa 6. novembra 2014 na Fakulte práva Paneurópskej vysokej školy v Bratislave. Žilina: Spoločnost’ pre trestné právo a kriminológiu, 2015, p. 65.

39 MEDELSKÝ, 2015, p. 216. 
Mendelskýt ${ }^{40}$. According to opinion of various experts this separate law does not include the Victims 'directive and that is why it needs to be amended soon.

Certainly, we may agree with Medelský and many other authors that the Slovak Republic has to take a giant step in front, which ultimately will help to ensure that victims of crime could effectively implement individual rights. ${ }^{41}$ This commitment arises not only from the directive itself or from the fact that leads the ENVR, but also from the moral perspective.

40 Ibid., p. 220.

41 Ibid., p. 221. 